\title{
$1 \quad$ Mediated Visibility as Making Vitriol Meaningful
}

\author{
Daniel Trottier, Qian Huang and Rashid Gabdulhakov
}

\begin{abstract}
When engaged in vitriol through digital media, users harm their peers not only through the caustic nature of their words, but also by the way in which they can make their targets visible to public scrutiny. Social platforms and mobile devices enable individuals to author commentary about their targets, but also compel other types of actors to join in (or to contest, appropriate or derail) malicious exchanges. By focusing on highly visible yet comparatively mundane forms of denunciation in China, Russia and the United Kingdom, this chapter considers how vitriol can be manifest as a form of civic engagement. These cases provide insight about a more prevalent form of vigilantism that may be located at the margins of what is considered acceptable in their respective social contexts.
\end{abstract}

Keywords: vigilantism, denunciation, digital media, social media, public space

\section{Situating vigilantism and visibility in relation to the study of vitriol}

When engaged in vitriol online, users harm their peers not only through the caustic nature of their words, but also by the way in which they can make their targets visible to public scrutiny. In addition to denunciatory and hateful language, it is important to consider the conditions in which these utterances are produced and circulated, especially in determining the severity of their social impact. Mediated visibility, notably the strategic and multi-actor manipulation of a targeted individual's visibility features prominently in vitriolic practices.

Polak, Sara, and Daniel Trottier (eds), Violence and Trolling on Social Media. Amsterdam, Amsterdam University Press 2020 DOI: 10.5117/9789462989481_CHO1 
Contemporary vitriol is primarily expressed through digital media. Social platforms and mobile devices enable individuals to author commentary about their targets, but also to compel other types of actors to join in (or to contest, appropriate, or derail) malicious exchanges. These other users, who we can tentatively consider as an audience, may simply view the content in question, a seemingly passive act that will be registered by the platform as a popularity metric, in turn contributing to the broader imagined community of judging onlookers. Technical features of social platforms and mobile devices, such as the ability to 'share' or 'retweet', as well as algorithms that sort and re-arrange volumes of user-generated content, extend the scope and range of vitriolic practices. Though some platforms might have been designed with particular professional or demographic contexts in mind, they can be adopted for any number of purposes, especially if these purposes end up serving the platform's business model of commanding attention and collecting personal information. As such, many sites have become gathering points for populist interventions. For example, in the context of Brexit, Facebook groups such as South East Alliance and Pie \& Mash Squad serve as venues for nationalist and anti-immigrant sentiment. ${ }^{1}$ This involves posting news articles and links to other extremist websites, as well as publishing vitriolic comments about targeted politicians, criminal suspects as well as entire categories of individuals in and beyond the United Kingdom. Such activities go far beyond Facebook's original and long-abandoned purpose of socialization among Ivy-league university students. While Facebook has expressed its commitment to removing such content, the platform remains one of several means for denunciatory and vitriolic coordination. ${ }^{2}$

Alongside more coordinated and politicized gatherings social media also offer citizens the opportunity to express frustration about everyday concerns, for example in the context of shared public spaces. In response to incivilities witnessed on a train, a bystander may digitally intervene by uploading evidence of the offending act, along with denunciatory words that capture their dismay. Such denunciations may be spontaneous, and one can imagine that they may be driven by civic motivations (for example, the desire for a safe and orderly daily commute) as opposed to furthering struggles between hegemonic and subaltern communities. Yet other users with diverging intentions can join in such denunciations by adding their own comments, sharing the footage with their social networks, and even supplementing it with additional details about the targeted individual or

$1 \quad$ Poulter, 'The Far Right Are Uniting'.

2 Thompson, 'How Facebook Checks Facts'. 
broader community. As a result, such denunciations can be co-opted for other purposes. They can also have a lasting impact on the lives of those targeted, as well as those belonging to the same (often disadvantaged) communities.

This kind of crowdsourced vitriol is a global phenomenon. Silicon Valley platforms such as Reddit and Twitter play a far-reaching role in denunciations and harassment in countless non-Western countries. Yet mediated vitriol is equally a local and nationalized phenomenon, with users in countries like China and Russia making either exclusive (in the case of the former) or preferred (in the case of the latter) use of national-origin platforms. In addition to national divergences, there are also instances of parallel online communities emerging along ideological lines. As conventional social media platforms have begun to monitor and curtail hate speech, ideologically bespoke platforms such as Voat and Gab have each gained prominence as Alt-Right equivalents to Reddit and Twitter, while Hatreon emerged as an alternative to the fundraising site Patreon. ${ }^{3}$

By focusing on highly visible forms of denunciation, this chapter considers how vitriol can be manifest as a form of civic engagement. These cases may amount to a reassertion of moral boundaries, which typically also carry identity-based dimensions. For this reason civic-led denunciations can become discriminatory and exclusionary, especially when this becomes a crowdsourced effort (which they are designed to be). Fleeting and situated moments of frustration may lead to a singular moment of mediated denunciation, which in turn may culminate into something much more impactful. Vitriolic words may - knowingly or otherwise - mobilize journalists, populist organizations, and politicians along with their respective followers. This chapter considers a particular form of digitally mediated harassment that relies on the denunciation and sustained visibility of others. In the cases considered below, the image of the target is made accessible to an amorphous and volatile audience. By editorializing an event, users invoke a moral compass that can garner further attention and harm. Moreover seemingly 'online' interactions are not distinct from offline consequences, but rather are intimately connected, and can create and exacerbate problems in embodied contexts.

Previous scholarship considers online mobilizations from the lens of (digital) vigilantism. ${ }^{4}$ This refers to instances in which digital media users are offended (or feign being offended) by the words or actions of others, and seek to make both the offence and the targeted individual visible for 
punitive measures. Recent cases vary greatly in terms of offending acts, ranging from minor incivilities to criminal acts that capture public attention such as child exploitation and participating in riots. Likewise, public sentiment about the appropriateness of these denunciations may also vary significantly. A common feature in such cases is the inclusion of vitriolic discourse, which can be observed both in the initial denunciations, as well as in the ensuing commentary by a wider audience. However, the caustic nature of these words cannot be assessed in isolation. Rather, social harm is brought about through the manner in which these statements are seamlessly joined together with description of someone (including images and audio-visual footage) and their associations (including family, workplace, and communities to which they belong). An amplification of the target's visibility leads to an amplification of any potential abuse.

Such developments speak to the ambivalence many users share about being visible online. On the one hand, digitally mediated visibility is partially self-asserted, and can be understood as a reasonably accessible form of self-expression and self-actualization. After all, in the vast majority of cases users knowingly decide to upload information about themselves to social media platforms. Even from a surveillance-studies perspective, being under the watchful eye of others can be understood as participatory and even empowering. ${ }^{5}$ Yet the sharing and subsequent circulation of that content may exceed the target's expectations. In cases where digital media users denounce and coordinate against a target in response to statement or photograph that the target uploaded themselves, we may imagine that they were willingly engaging in some kind of self-expression, for example, to a group of peers. This speaks to how digitally mediated visibility is a collaborative and decentralized endeavour, with several types of actors sharing no institutional or ideological alignment recirculate content originally posted to a social media account. Vitriolic discourses also act as a mobilizing force that invokes a broader audience either in support or against the denunciation. Yet either way it prompts a reaction, and ensures further visibility of the target and the initial message. Such efforts typically culminate in a targeted individual being rendered excessively visible as an object of discussion, without a reasonable opportunity to provide a response.

Unless the digital vigilante chooses to remain anonymous, their exposure and denunciation of a target can lead to themselves becoming the target of a potential counter-denunciation. This possibility reflects the fact that acceptable norms about filming and denouncing others are still being 
negotiated in the mediated public sphere. It bears noting that cases of digital vigilantism cover a moral gamut, and as such include offending acts that trigger widespread condemnation (such as the sexual abuse of children), as well as actions not necessarily considered objectionable by a broader audience (such as eating on public transit). Even in cases of widely condemned offences, public opinion may not support such interventions. For these reasons, scholarship must continue to focus on the public shaping of the perceived acceptability of digital vigilantism. Of particular concern here is the role of the state. By definition it remains excluded from participation in vigilante activities. Yet states may endorse or even financially support citizen-led initiatives, and make use of media channels to attempt to shape public perception of such movements.

The following sections provide an overview of contemporary vitriolic and vigilante landscapes in three national contexts: the United Kingdom, China and Russia. For each country we consider a recent case, and make use of press representations as well as other publicly available data about the event. In contrast to immediate responses to high-profile criminal acts that have been covered in other research, these cases are centred on comparatively banal incidents occurring in public spaces. ${ }^{6}$ These cases provide insight about a more prevalent form of vigilantism, one that may be located at the margins of what is considered acceptable in their respective social contexts. The purpose in juxtaposing them is not purely comparative, but rather to identify commonalities and divergences as topics for subsequent in-depth analysis.

\section{United Kingdom: Disability and disregarded train seat reservations}

While it would be impossible to provide an exhaustive account of UK-based mediated shaming and vigilantism in this chapter, what follows is a case study that provides both recent developments as well as historic antecedents. As such, we do not seek to establish causal links between any single media format, and user activity. Although online shaming may be considered as a product of digital media cultures, a cursory overview of punitive technologies in the UK reveals an array of embodied devices such as the pillory or the scold's bridle, which restrained the targeted individual's movement as well as speech. These served not only to punish transgressions, but in particular

6 Nhan et al., 'Digilantism'; Schneider and Trottier, 'Social Media'. 
to do so in a public manner that disciplined both the target as well as those belonging to the same category, such as 'quarrelsome women' in the case of the scold's bridle. ${ }^{7}$ Likewise, citizen-led interventions such as charivari and rough music had a distinctly public and performative character, in that they served to convey to a broad array of actors both the nature and the consequence of a transgressive act. ${ }^{8}$ The emergence and establishment of tabloid press furthered the scope and visibility of such denunciatory acts. In particular, these facilitated the circulation of imagery of a target of scorn, as well as vitriolic accounts of the target that had a broader and more lasting public reach.

We might think of digitally mediated shaming and its co-construction with British tabloids as a recent development. Yet as far back as 1998 the articles described how '[c] omputer hackers' were 'becoming cyber vigilantes' in order to combat paedophilia, a social problem that received substantial media coverage at the time. ${ }^{9}$ Such anti-paedophile vigilantes have consistently been presented in public discourse, often in conjunction with legal mechanisms. For example, Sarah's law sought to enable the UK public 'to find out if an individual in contact with a child has a record of child sexual offences' through formal legal means. ${ }^{10}$ Other prominent cases include responses to animal abuse, such as the outrage that a Coventry woman received in 2010 when placing a cat into a garbage bin. Women have also been on the receiving end of online scrutiny for a range of other reasons in the UK, such as eating on public transit. ${ }^{11}$ In such cases, the press and tabloid media in particular served as prominent accounts of developments. In recent years there have been a number of cases in which digital media users have witnessed antisocial behaviour in public settings, and have uploaded photographs and their own accounts to their personal social media profiles. We consider one such case below.

In September 2016, a woman took a rush hour train from London to her hometown. She had a seating reservation in order to cope with a disability that left her in great discomfort if left to stand. Upon arriving at her seats (one of which was reserved for her caretaker), she encountered two men who occupied them and refused to move. She took a photograph of the men, and uploaded it to Facebook with her description of what transpired.

8 Johnson, 'Charivari/Shivaree'.

9 Blackstock, 'Hackers Make War', p. 10.

10 Sarah's Law.

11 Sanghani, 'Why This Man Takes Photos'. 
Several aspects of this post are worth noting. First, she identifies herself as a disabled passenger, explaining the additional necessity of the reserved seat, and further explaining why the offence in question is so actionable. She also includes the train time as well as destination, making the incident not only legible but also locatable to an undetermined audience, which may include journalists as well as representatives from the rail company. While avoiding explicitly vitriolic language, she makes extensive use of sarcasm, referring to the targets as 'gentlemen' and 'charming fellows', noting that their 'wives and mothers would be proud.' The latter is especially relevant, as through these words this statement not only appears to invoke a broader social network to bear witness to this offence, but in particular names the female members of the targets' families for additional scrutiny and shaming (potentially of and by these women). Further categories are invoked in this denunciation, as the author notes that the two men were discussing luxury holidays. This, combined with the business attire that both men are wearing in the accompanying photograph, characterized the targets as socially aloof businessmen.

The first news articles reporting this incident were published the following day, mostly in national and regional tabloids. These articles provided coverage of both the offending act as well as the mediated denunciation. Indeed, these initial reports relied heavily on the Facebook post and photograph, often quoting its text in article titles as well as throughout the copy. Previously invoked categories such as 'disabled woman' and 'businessmen' also featured prominently. These journalists take some steps to distance their reporting from the initial denunciation, for example, through the use of quotation marks and terms such as 'it is claimed'. ${ }^{12}$ Yet this press coverage largely serves to reproduce the discourse of the Facebook post. In the following days, subsequent articles provided additional perspectives of the incident on the train. This included one of the targets along with his father, as well as a friend of the disabled woman. Full names were often included, though reports also indicated when people (such as one of the two targets) wished to remain unnamed. These additional perspectives provided some nuance to the original incident, for example, by revealing that seat reservations had allegedly been cancelled on the train, and that the two targets claimed that they did not know the woman in question had a disability. These perspectives also served to extend coverage of the incident by an additional two days. Later articles also featured quotes from spokespeople of the rail network, who provided insight regarding the company's 
reservation policies. Articles appeared in these newspapers the following week that made passing reference to the incident. They included comments from readers either supporting or condemning the initial denunciation, as well as journalists' own editorializing. Here, authors often scaled up their denunciation to target broader societal conditions such as entitlement culture and 'the nature of our violent society'. ${ }^{13}$

This reporting provides a pattern that can be found in other UK-based cases, in which a citizen uploads a denunciatory post on social media, and the press pick up on it over the course of the following days. In doing so the press call further attention to the cases, and the people implicated in them. Their framing of these cases may also shape public perception of the offending incident and response. As the original posts may be deleted or hidden through privacy settings, press coverage allows for a wider and more enduring audience. This audience may provide vitriolic comments when speaking to journalists, commenting online, or sharing links of these articles on their own social media accounts.

\section{'Unqualified as a mother and teacher': Vitriol against a female passenger on a high-speed train in China}

In Chinese history, policing has been conducted by the state through nonphysical coercion in addition to physical violence. This combined method is partly due to the influence of Confucian philosophy that the best way to maintain order is to establish intrinsic morality instead of strict rule, regulations and laws. The self-policing that is required by such a principle was practiced by people in a form of 'village pacts' in the Zhou Dynasty and became prevalent in the Song Dynasty. ${ }^{14}$ The village pact was essentially a form of neighbourhood surveillance and mutual warnings in response to breaches and transgressions that were regarded as harmful for the public welfare. The punishment to such breaches and transgressions were mostly non-physical spectacle of the dishonoured family, such as posters on the door, social isolation, expulsion from the pact and the registration of evil deeds. ${ }^{15}$

In contemporary China, vitriol is used as a tool of self-policing as well. On social media platforms, such punitive policing follows the exposure of illegal behaviours of various severities, from minor violations of traffic 
regulations, physical conflicts between individuals, to child abuse and paedophilia. Citizens also express their disappointment with the current Chinese legal system for not being comprehensive enough to govern the wide range of social activities. These issues are mostly immoral but legal or legally unclear, such as animal abuse, marital disputes and incivilities on public transportation. There are also denunciations reflecting an emerging online nationalism, which support state narratives and discipline those who challenge the state by rendering them visible online and shaming them with vitriolic statements.

Participants typically initiate vigilantism on private-owned social media platforms, such as Sina Weibo, Baidu Tieba, Douban, Tianya, among others. ${ }^{16}$ After its establishment in 2009, Sina Weibo in particular has become the major platform where most influential online incidents take place, including vigilantism. ${ }^{17}$ Government accounts (including local police agencies and state ministries) post their own content and interact with net-citizens (netizens) on a daily basis according to a 2017 statistical report. ${ }^{18}$ State-controlled and commercial media are highly active on Sina Weibo. Individual users, including civilians, celebrities and public opinion leaders also routinely produce, consume, and disseminate information on this platform.

Mass media and state institutions perpetuate the mediated visibility of vitriol. In China, state-owned and commercial media have different roles, characteristics and relations with the state. Commercial media are private companies and enjoy a relatively greater degree of freedom in terms of topic choices and editing. ${ }^{19}$ Some commercial media, such as Pengpai News Agency, Xinjingbao, Caixin, and Phoenix benefit from the reputation of keeping up with trending societal issues. They report on and provide dedicated columns for hotly debated incidents. On the contrary, state-owned media started as part of the state propaganda apparatus from the establishment of People's Republic of China to the Opening and Reform in 1978, and their administrative and staffing issues are still directly controlled by the state even though they enjoy relative freedom in terms of their daily operation.

16 Sina Weibo is a microblogging platform, usually regarded as the 'Chinese Twitter'. Baidu Tieba is a bulletin board system established in 2003 that aims to provide a platform where people with the same interests can find each other by keyword searching. Douban is a website established in 2005 that provides user generated content of films, music, books etc. Tianya is a social networking site established in 1999 that focuses on life and emotions in forms of user generated forums and blogs.

17 Sullivan, 'A Tale of Two Microblogs'.

18 CNNIC, '2016 China Statistical Report'. 
In addition, reports from state-owned media usually feature government announcements and responses. When an incident is regarded as a threat to social stability, however, state-owned media also produce articles of greater length to analyze the issue and provide a state-desired perspective and conclusion. In addition to state-owned media, the government has furthered the involvement of law enforcement in online matters. From 2015, Internet Police in fifty cities started their own Weibo, WeChat, and Baidu BBS accounts, in order to deter and stop cybercrime, harmful speech and behaviours, and to act on netizens' reports about illegal behaviours on the Internet. ${ }^{20}$ The Internet Police is a state police division that is solely responsible for policing various Internet crimes, including online threats, spamming, pornography, terrorism, hacking and fraud. While the Internet Police encourages citizens to provide information in order to fight crimes, the exposure of individuals' personal information acquired illegally is outlawed. The establishment of such systems encourages citizens' online self-policing. For this reason, Chinese citizens engage in vigilantism on even minor transgressions with firm denunciations. Facilitated by a widely networked platform - Sina Weibo - and perpetuated by the broader media landscape, such visibility and vitriol tend to amplify and prolong the impact on individuals. We may consider a recent case about a minor transgression on public transportation.

In January 2018, a woman impeded a train's departure because her husband was denied entry at the boarding gate. A passenger recorded and shared the conflict and the video went viral. The woman was given a penalty of 2 , ooo yuan (roughly $300 \mathrm{USD} / 255$ Euro) and later suspended from her job as a deputy dean in a primary school. She appeared in two interview videos before and after the punishment was announced. In the first interview for a privately-owned short-video streaming website, she insisted that it was just a matter of ten seconds so that her husband could make it to the train and wondered why her behaviour was so poorly regarded. In the second interview on the CCTV (China Central Television) News Channel, she admitted that she was overreacting and caused troubles for both the railway staff and passengers, and wished to apologize, hoping that netizens would forgive her.

In the video that shows the transgression, the person behind camera constantly reminds the woman of the illegality of her behaviour: 'Do you know it is illegal to do so?' The shared video on Weibo provoked netizens' denunciation with vitriol against the woman. There are between 4000 and 7000 comments under each post from five major media Weibo accounts. Four 
types of vitriolic utterances can be observed among the above-mentioned comments. The first type is normative evaluations of her behaviour. She is regarded as a person who 'has no respect of punctuality', 'has a horrible public manner', 'is unreasonable and making a scene', and 'endangers others' safety', which are concerning the qualities that a good citizen should have. In addition to direct negative evaluation of her behaviour, there are comments referring to her identity and social roles, including teacher, mother, and woman. Netizens show disgust by expressing concerns about her students and daughter: 'I can't imagine what kind of people/person her students/ daughter will become'. She is regarded as 'unqualified as a teacher/mother', and having 'tarnished the occupation/the title 'mother". She also received gender-specific vitriol such as 'shrew', and comments that emphasize her gender with terms like 'as a woman...'. These utterances imply that a higher moral standard should be required for teachers, mothers, and women. Insulting and vulgar language are also observed in comments, such as calling the woman 'psycho', 'trash', regarding her as 'despicable', 'disgusting', asking her to 'fuck off', and wishing for her to suffer in the future through 'getting a divorce', 'being beaten up', and 'losing her job forever'. Sarcasm is a common strategy. For example, 'dear teacher, ... you taught us a valuable lesson that anything can be sacrificed for our own good...' is an instance of vitriol disguised in praise. Netizens' responses target law enforcement for being too soft when forcing out the woman and giving her a penalty: 'The law enforcements treat their own rules as shit; no wonder people keep breaking it.'

The woman's apology also attracts vitriol later. Netizens regard her apology as insincere because 'She kept finding excuses for her behaviour' and conclude that 'she's only apologizing because her life was ruined'. They accuse her of lying in order to gain sympathy: 'she has her ID card in her hand on the video (she claimed her husband had her ID card in the apology video). How dare she lie about such obvious thing! Does she think that all the netizens are retarded and have no common sense?'. They decide that they would not forgive her: 'she deserves it!' 'NEVER!' 'We won't need police if apology works'. These responses reveal an intention to socially exclude an individual who has misbehaved. User-led policing through vigilantism and can greatly harm a targets' social standing, perhaps more so than through other policing mechanisms because an opportunity for rehabilitation is not provided. Instead, social exclusion for an undetermined period of time appears to be the desired outcome.

Commercial media play an essential role in perpetuating such long lasting visibility. Most commercial media provide the offender's name or last name, 
her job, and the school that she works for in their coverage. By mentioning the target's occupation, commercial media implicitly echo netizens' assumption of a higher moral standard for teachers. While state-owned media refer the target as 'a female passenger' most commercial media and social media articles refer the target as 'a female teacher'. ${ }^{21}$ Some commercial media divert discussion in order to focus on the occupation. A journalist posted a special column entitled 'How can directors of discipline avoid becoming monsters who stop the high-speed train' on Tencent News, in which he emphasizes that teachers and other authority figures are easily 'alienated by the power they have at schools.'. ${ }^{22}$

The majority of commercial media reports reproduce netizen vitriol in criticizing the offender's lack of citizenship. They point out the potentially severe outcome of the offender's behaviour, stressing that any disruption of train schedules might affect the dispatching of trains in different routes, and conclude that the offender lacks awareness of regulations and laws. There are also commercial media such as Xinjingbao, which have a reputation of reporting from different perspectives, giving the offender an opportunity to explain herself and questioning the punishment and online vitriol. However, netizens denounce the newspaper's editors and reporters for 'trying too hard for attention'. In contrast, state-owned media comment mainly on the general social implications of this incident. Beijing Daily emphasizes the necessity of citizenship training in terms of respecting the rule of law and the contract spirit. Guangming Daily criticizes the commercial media and some netizens for putting occupational labels on the offender, diverting the discussion and fanning the flame. ${ }^{23}$

\section{Smile douchebag-you are on camera: Collectively mediated vitriol in Russia}

It can be argued that current digitally mediated cases of collective denunciation and vitriol in Russia are largely influenced by the country's Soviet past, where the public's involvement in exercising justice over fellow comrades was a prevalent and encouraged practice. ${ }^{24}$ In cases of minor mischief, the delinquent was confronted through a system of comrades' courts where 
judge and jury were comprised of colleagues and neighbours. The severity of the shameful impact of such collective justice could be amplified through display of the target's portrait on special boards of shame and through exposure in the local paper. ${ }^{25}$ Nowadays, mediated vigilantism in Russia still principally takes place as an encouraged, organized and systematic practice with an issue-specific retaliatory focus.

This section of the chapter seeks to provide a general overview of cases and trends related to mediated vitriol in contemporary Russia. From a seemingly universal practice of exposing alleged paedophiles to rather unique engagements with drivers and merchants, active citizens in Russia have been finding offence in fellow citizens, retaliating, and exposing them across global and domestic social media platforms. Soviet boards of shame have been replaced with YouTube, Facebook, and VKontakte; ${ }^{26}$ while traditional media outlets continue to widely report on 'loud' cases, rendering additional layers of visibility and exposure.

In Russia, organized acts of retaliation by citizens against fellow citizens share a common scenario where targets are confronted over offences while the process is filmed and the footage is spread widely. Vigilantes across the country have formed movements focused on specific offences. Some of these formations turn into recognizable brands. Among such brandlike vigilante groups are StopXam [Stop a Douchebag] and Hrushi Protiv [Piglets Against],${ }^{27}$ specializing in combating traffic violations and exposing 'unscrupulous' merchants respectively. Founded in 2010 by members of Russia's state-organized youth movement Nashi [Ours $],{ }^{28}$ both formations were endorsed ${ }^{29}$ and funded by the government. ${ }^{30}$ Given this unique scenario where the state encourages an etymologically citizen-organized practice of vigilantism, it is important to consider, among other factors, the motives behind both organization and participation.

In widely available videos that have been viewed by millions, StopXam members approach the drivers and ask them to re-park their cars. If the driver does not comply, a sticker that reads 'I Spit on Everyone I Drive Where I Want ${ }^{\prime 31}$ is placed on the windshield of the vehicle, usually sparking hostility accounts of the groups.

28 Kurochkin and Nikoforov, 'Civic Initiatives'.

29

Kurochkin and Nikoforov, 'Civic Initiatives'.

Original translation orthography used by StopHam is preserved. 
as well as verbal and physical confrontations between participants and targets. The shameful signs are difficult to remove and are intended to serve a 'disciplinary purpose, as the driver should think about their behaviour while scratching off the sticker'. ${ }^{32}$ Some drivers receive several stickers during a single confrontation, which will impede their ability to drive off due to their restricted visibility.

Dressed in full-body piglet costumes, Hrushi Protiv target allegedly unscrupulous merchants and expose them online. Participants raid markets and grocery stores with the aim of disclosing expired products. Seeing a dozen 'piglets' browsing the aisles, the personnel confronts the selfproclaimed auditors, sparking verbal and physical assaults between both parties. All raids are filmed, and edited footage is spread across social media. Content analysis of video material produced by Hrushi Protiv reveals a bias against merchants of non-Russian descent. The group frames people from the Caucasus ${ }^{33}$ and labour migrants from the former-Soviet Central Asian republics as responsible for expired produce on the shelves of Russia's stores. In 2014, Hrushi Protiv called on its audience to sign petitions to 'condemn migrants from working in retail'. 34 Though it received marginal online support, this call for action is suggestive of a political stance of the group. Along with proportionality of retaliation, questions concerning political instrumentalization of digital vigilantes inevitably arise.

Virtually every video produced by StopXam and Hrushi Protiv contains cases of violent verbal or physical confrontations and shaming of the drivers and the merchants. These confrontations and mediated public shaming serve as both entertainment and disciplinary show for the passer-by, for the online audience, and for traditional media consumers when featured on TV and in newspapers. Both groups publish several videos per month and possess editorial powers, which grant them the ability to frame the target and the process of retaliation. ${ }^{35}$ Unless they are famous people with a large social media following, targets have limited options to generate a counter-narrative. If a digital vigilante group has an audience of millions, their target with a few hundred friends on social networks cannot compete with such social outreach. ${ }^{36}$

33 Some Republics in the Caucasus are part of the Russian Federation. Nevertheless, due to ethnic biases, Russian citizens from the Caucasus are sometimes perceived as alien migrants not only by Russian nationalists, but also by immigration and law enforcement officers.

34 Russia's Public Initiative, 'Call for a legislative ban'.

35 Gabdulhakov, 'Citizen-led Justice', p. 327.

36 Gabdulhakov, 'In the Bullseye of Vigilantes', p. 233. 
Videos produced by vigilantes are actively commented on by the viewers. While some viewers question the acts of participants, the majority express solidarity and condemn targets in a biased fashion. Videos where drivers and merchants are framed as non-Russians are commented on in the following manner: 'this is a zoo, not a store', or 'as always, the mountain folk is acting like animals', 'they are used to riding donkeys in their villages, and here they have to abide the rules'. Comments also bring up speculations about the targets' legal status in Russia: 'they are afraid of cameras because they do not have a registration', 'why is every other Central Asian so afraid of cameras? Are they illegals? I suggest our immigration forces look closely at this group'.

While traditional media could theoretically serve as a platform for targets to deliver their side of the story, media analysis reveals that Russia's mainstream broadcasters rely on participants' footage as evidence, which is an explicitly subjective representation of events. Traditional media coverage leads to greater exposure of targets and profile raising of vigilantes, making the latter appear as an omnipresent eye of the public. Words such as 'activists', 'youth', 'public movement', and 'volunteers' have been used by Russia's mainstream media outlets to define StopXam and Hrushi Protiv. In reference to the targets, media reports tend to use phrases such as 'aggressive' and 'inadequate'. A number of media reports make direct references to the targets' ethnic and national backgrounds through use of othering wording such as 'the Chechens', or 'people from the Caucasus', or 'the Tajiks', thus copying vigilantes' biases and prioritizing ethnic origins and nationality as identity markers for the 'bellicose' targets.

What is distinguishable in digital vigilantism is the severity and longevity of retaliation. For instance, for grocery stores, an inspection by state consumer protection services could lead to investigations and any shortcomings would end in fines for the concerned retailor, without the public necessarily getting involved in mob justice, chanting and pointing out the ethnic origin of the manager or other employees. In current practices of mediated vitriol and exposure, the concerned retailer's reputation can be severely damaged without any legal investigation, but by means of edited video reports produced by self-proclaimed auditors. These circumstances grant peculiar powers to participants, as, theoretically, they can be hired by competitor stores as 'reputation assassins'. Some large retailers in Russia even went as far as signing special collaboration agreements with Hrushi Protiv, ${ }^{37}$ which grants further legitimacy to otherwise unsanctioned raids. 
Social media platforms play a unique role as providers of a stage for vigilante practices. This role is not a passive one, as terms of use as well as state legislation in which platforms operate govern harmful and inappropriate content. Platforms can rate certain videos as $18+$, remove them, filter commentary, and otherwise censor users. Arrests over 'likes' and 'shares' on social media have sprawled across Russia in recent years. ${ }^{38}$ However, sometimes no action is taken against users. ${ }^{39}$ YouTube, in this regard, is successfully instrumentalized by both StopXam and Hrushi Protiv, with millions of viewers and income generated through advertisements. Videos with obscene content freely circulate the web, which reflects the default involvement of platforms in disseminating vitriolic confrontations and exposure of targets. Global circulation of videos grants recognition to participants far beyond their local communities. Both StopXam and Hrushi Protiv have branches in other former Soviet republics and in the case of the former, even on other continents. ${ }^{40}$

The combination of social justice practices and political agendas reproduces a convoluted dynamic between the state, participants, targets, media platforms (both traditional and social), as well as the audience. ${ }^{41}$ In such a setting, the boundaries of power division are blurred, proportionality and legality of retaliation become questionable, and citizen-on-citizen retaliation takes on a totalitarian and pervasive mode.

\section{Discussion}

While these three examples of mediated vigilantism concern different political and cultural contexts, some common features stand out. Each case is a response to incivilities that take place in (quasi-)public spaces such as grocery stores, shared roadways and train carriages. We can imagine these to be contested terrains due to external factors such as the edacity of markets, a scarcity of seating/parking, or a surfeit of passengers or vehicles. In addition to witnessing laws and regulations being violated, we may

38 Bevza, 'To Fabricate a Case'.

39 Although StopXam was officially liquidated in 2018, Ministry of Justice of Russia made the decision over the group's violation of accounting procedures, and not over video content or vigilante practices.

40 StopXam prototype Mal Estacionado [Bad Parking] was opened in Lima, Peru, upon approval of the original group in Moscow.

41 Manifested through a hierarchy of power, from the highest ranks of policymakers to police officers on the ground and other state entities whose functions are performed by digital vigilantes. 
also speculate whether a sense of entitlement to these spaces may further compel citizens to denounce those who are deemed to breach a moral order. Furthermore, we can speculate whether such a sense of moral order may also be sought in quasi-public digital spaces when vigilantes retaliate against online incivilities.

These cases also raise the question of who is entitled to speak out against their peers. In order to succeed in openly denouncing someone, digital media users depend not only on an audience for support, but also on the press to provide further coverage of the incident. In all three cases we see that mediated vitriol is above all else a collaborative effort. In turn, newspapers source quotes from online posts, reach out to friends and family of those who are implicated, and invite readers to comment and share reports as well. This is partly out of necessity, in order for journalists to produce a news-story out of what often begins as a social media post. Yet it also demonstrates one manner in which media assemblages work: through temporary partnerships and collaborations with a range of actors. As such, even toxic and anti-social discourse may become a core component of routine news cycles.

A further commonality to these cases is that even when a single individual is being targeted, the denunciation itself also mobilizes social categories. Offensive conduct in trains and on streets is rhetorically coupled to broader representatives of a particular ethnic group or nationality, groups like the wealthy, as well as professions such as teachers, with all the social expectations that are bundled with such a position. Shaming and vitriol are typically gendered as well, with denunciations serving as an opportunity for citizens to air grievances against 'shrews' and those deemed to be unfit mothers.

All three cases demonstrate how vitriol and mediated visibility are related: afforded by digital platforms, denunciation accompanied by vitriolic discourse makes individuals visible online, which provokes further translocal denunciations against them. Such vitriol and visibility are most likely to be amplified by traditional media, which adds to the layered harm inflicted on individuals. Therefore, the contemporary study of vitriol in media needs to consider how targets are rendered visible. Mediated visibility may serve as a kind of force multiplier for leveraging harm against a target or a community. In particular, these mechanisms further serve to persecute and marginalize women and members of disadvantaged communities. Religious, ethnic, gender, and other prejudices come to surface in cases of citizens' collective response to perceived infraction committed by target. In a recent incident in Russia surrounding a public discussion of sexual assault the common narrative in response to the female victim of sexual violence is 'you should 
not have seduced the man' and 'what were you doing at a party anyhow'. ${ }^{2}$ This narrative is backed with legislation decriminalizing some domestic violence and softening punishment for first offence in sexual assault. ${ }^{43}$ In many cases, targets of digital vigilantism are limited in their options of seeking justice. Going public with the case can lead to an ever-greater exposure, shaming, and societal condemnation. Gender, sexual, national, ethnic, religious and other flaws and biases set ground for layers of vulnerabilities among some members of the society. ${ }^{44}$ In the aftermath of terrorist attacks in Russia's major cities, the promptly identified suspects tend to be 'Muslim-looking' males from the Caucasus. In one such instance the wrongly accused target reported themselves to police, in order to prove their own innocence and restore a damaged reputation. While police confirmed the person's innocence, the mediated exposure turned out to be difficult to revert. When attempting to travel back to his hometown, the target was forced off the plane by other passengers and faced perpetuated instances of questioning by police and short-term arrests. 45

It is therefore important to take a scholarly and societal approach towards mediated harassment that recognizes that while potentially anybody can be targeted by collective scorn and denunciation, these mediated practices typically reproduce and even aggravate existing disparities. In terms of directions for subsequent research, scholars should further consider links between media studies and criminological accounts of vitriol in denunciatory contexts. In particular, they should consider vitriolic denunciation as a chain of mediated events, rendered meaningful through networks of decentralized actors. The above cases suggest that press coverage of denunciations may significantly contribute to the exposure and harassment of a targeted individual, and this is a topic scholars should continue to examine. Yet we should also be mindful of our own potential contribution to mediated exposure and shaming through our analysis of prominent as well as relatively obscure cases. We can take steps to attempt to protect the identities of those involved, yet our reliance on press coverage may still render them identifiable. And while the readership of an academic text may pale in comparison to a viral social media post or tabloid article, it may remain archived and potentially accessible to a wider audience. 
When searching for remedies to online vitriol, one cannot simply mute the so-called 'court of public opinion'. ${ }^{46}$ From a practical standpoint, mediasavvy audiences can take advantage of multiple platforms, and spill out into the comments sections of any online newspaper, or the reply function of any social platform. The fact that such visible opinions (in the forms of comments and replies) can either be fuelled by strategically constructed (fake) news, or itself the product of a Twitter bot, remains a pressing concern. As well, self-erasure or self-censorship is neither sufficient to prevent receiving online vitriol, nor is it a desirable state of existence for potential targets. As the examples above demonstrate, other individuals and institutions make use of one's social visibility. Remedies for specific instances of vitriolic harassment, as well as more general strategies for prevention, need to prioritize the autonomy of the person being targeted.

\section{Works cited}

Albrechtslund, Anders. 'Online Social Networking as Participatory Surveillance'. First Monday, vol. 13, no. 3, 2008, https://firstmonday.org/article/view/2142/1949.

BBC. 'Russian MPs Pass Bill to Soften Domestic Violence Law'. BBC.com, 27 January 2017, https://www.bbc.com/news/world-38767873. Accessed 26 October 2018.

Beijing Daily. 'Lan Gaotie Shijian Shitang Guize Yishi Gongkaike'. Beijing Daily, 12 January 2018, https://www.weibo.com/ttarticle/p/show?id=2309404195357461480177. Accessed 20 March 2018.

Bevza, Dmitry. 'Narisova's Delo: Kak v Rossii Sazhayut za Reposti'. [To Fabriate a Case: How Russia Arrests for Shares]. Gazeta.ru, 19 August 2018, https://www.gazeta. ru/tech/2018/08/18/11899507/two_years.shtml?updated. Accessed 15 July 2019.

Blackstock, Colin. 'Hackers Make War on Net Paedophiles'. The Independent, 6 September 1998.

Chandler, Mark. 'Disabled Woman Posts Facebook Photo of Businessmen 'Refusing to Give up Her Reserved Seats' on London Train'. London Evening Standard, 21 September 2016.

Chinese Ministry of Public Security. 'Jianli Wangjing Changtaihua Gongkai Xuncha Zhifa Jizhi', 2015, www.mps.gov.cn/n2255079/n4876594/n497459o/n4974592/ n5116794/index.html. Accessed on 20 March 2018.

CNNIC. '2016 China Statistical Report on Internet Development'. http://www. cnnic.net.cn/hlwfzyj/hlwxzbg/hlwtjbg/201708/Po20170807351923262153.pdf. Accessed 20 March 2018. 
Dobash, Russel P., and R. Emerson Dobash. 'Community Response to Violence Against Wives: Charivari, Abstract Justice and Patriarchy'. Social Problems, vol. 28 , no. 5 , 1981. pp. 563-581.

Dowle, Jayne. 'Why We Must Not Stand for Selfish People Who Disregard the Disabled'. Yorkshire Post, 26 September 2014.

Dutton, Michael R. Policing and Punishment in China: From Patriarchy to 'the People'. Cambridge (UK): Cambridge University Press, 1992.

Gabdulhakov, Rashid. 'Citizen-led Justice in Post-Communist Russia: From Comrades' Courts to Dotcomrade Vigilantism'. Surveillance \& Society, 16, no. 3, 2018, pp. 314-331, doi:10.24908/ss.v16i3.6952.

-. 'In the Bullseye of Vigilantes: Mediated Vulnerabilities of Kyrgyz Labour Migrants in Russia'. Media and Communication, 7, no. 2, 2019, pp. 230-241, doi:10.17645/mac.v7i2.1927.

Gabowitsch, Mischa. 'Are Copycats Subversive? Strategy-31, the Russian Runs, the Immortal Regiment, and the Transformative Potential of Non-Hierarchical Movements'. Problems of Post-Communism, vol. 65, no. 5, 2016, pp. 1-18.

Guangming Web Critic. 'Weiguan Gongong Shijian, Shaoyidian Biaoqian'. Guangming Daily, 14January 2018, http://guancha.gmw.cn/2018-01/14/content_27345819. htm. Accessed 20 March 2018.

Johnson, Loretta. 'Charivari/Shivaree: A European Folk Ritual on the American Plains'. The Journal of Interdisciplinary History, vol. 20, no. 3, 1990, pp. 371-387.

Kremlin. 'Rasshirennoe Zasedanie Kolleggii MVD Rossii'. [Extended Meeting of the Board of the Ministry of Internal Affairs of Russia], 2017, http://kremlin.ru/ events/president/news/54014. Accessed 13 August 2018.

Kupfer, Mathew. 'How Russia Turned on a Teenage Rape Victim'. The Moscow Times, 8 March 2017, https://www.themoscowtimes.com/2017/03/o8/how-russia-turnedon-a-teenage-rape-victim-a57368. Accessed 13 August 2018.

Kurochkin, Alexander, and Alexander Nikoforov. 'Civic Initiatives under Conditions of Network Society: New Challenges and Possibilities'. Modern Research of Social Problems, vol. 145, 2015.

Li, Duoyu. 'How Can Directors of Discipline Avoid Becoming Monsters Who Stop the High Speed Train'. Tencent Sage, 12 January 2018, http://dajia.qq.com/original/ category/ldy20180112.html. Accessed 20 March 2018.

Nhan, Johnny, et al. 'Digilantism: An Analysis of Crowdsourcing and the Boston Marathon Bombings'. The British Journal of Criminology, vol. 57, no. 2, 2017, pp. 341-361.

Poulter, James. 'The Far Right Are Uniting Around Their Right to 'Free Speech". Vice.com, 20 March 2018, https://www.vice.com/en_ca/article/j5axgd/the-farright-are-uniting-around-their-right-to-free-speech. Accessed 13 August 2018. 
Roose, Kevin. 'The Alt-Right Created a Parallel Internet. It's an Unholy Mess'. New York Times, 11 December 2017, https://www.nytimes.com/2017/12/11/technology/ alt-right-internet.html. Accessed 13 August 2018.

Russia's Public Initiative. “Zakonodatel'no Zapretit' Rabotu Migrantov v Sfere Torgovli'. [Call for a Legislative Ban on Migrant Employment in Retail], 2014, https://www.roi.ru/8873/. Accessed 13 August 2018.

Russia Today. “Leave Me Alone!': Misidentified St. Petersburg Bombing Suspect Says Life Has Turned into Nightmare'. RT.com, 5 April 2017, https://www.rt.com/ news/383619-petersburg-suspect-muslim-police/. Accessed 13 August 2018.

Sanghani, Radhinka. 'Why This Man Takes Photos of 'Women Who Eat On Tubes'. He Promises He Isn't a 'Weird Deviant”. Telegraph.co.uk, 7 April 2014, https:// www.telegraph.co.uk/women/womens-life/10749681/Why-this-man-takesphotos-of-Women-Who-Eat-On-Tubes.-He-promises-he-isnt-a-weird-deviant. html. Accessed 13 August 2018.

Sarah's Law. https://www.sarsas.org.uk/sarahs-law/. Accessed 13 August 2018.

Schneider, Christopher J., and Daniel Trottier. 'Social Media and the 2011 Vancouver Riot', in Denzin, Norman K. (ed). 4oth Anniversary of Studies in Symbolic Interaction, Studies in Symbolic Interaction. Bingley (UK): Emerald, 2013, vol. 40, 2013, pp. 335-362.

Stephenson, Matthew C. 'Court of Public Opinion: Government Accountability and Judicial Independence'. The Journal of Law, Economics, \& Organization, vol. 20, no. 2, 2008, pp. 379-399.

Sullivan, Jonathan. 'A Tale of Two Microblogs in China'. Media, Culture \& Society, vol. 34, no. 6, 2012, pp. 773-783.

Thompson, Nicholas. 'How Facebook Checks Facts and Polices Hate Speech'. Wired. com, 6 July 2018, https://www.wired.com/story/how-facebook-checks-facts-andpolices-hate-speech/. Accessed 13 August 2018.

Trottier, Daniel. 'Digital Vigilantism as Weaponisation of Visibility'. Philosophy \& Technology, vol. 30, no. 1, 2017, pp. 55-72.

Vigilantes. 'Hrushi Protiv', http://vigilant.myverdict.org/files/pigs. Accessed 13July 2019. Winfield, Betty Houchin, and Zengjun Peng. 'Market or Party Controls? Chinese Media in Transition'. International Communication Gazette, vol. 67, no. 3, 2005, pp. $255^{-270 .}$

\section{About the authors}

Daniel Trottier is an Associate Professor of Global Digital Media in the Department of Media and Communication at Erasmus University Rotterdam, the Netherlands. His current research considers the use of digital media for 
the purposes of scrutiny, denunciation and shaming. Daniel is the PI of a five-year NWO-funded project on this topic, entitled "Digital Vigilantism: Mapping the terrain and assessing societal impacts". He has authored several articles in peer-reviewed journals on this and other topics, as well as Social Media as Surveillance (Ashgate, 2012), Identity Problems in the Facebook Era (Routledge, 2013), and Social Media, Politics and the State (co-edited with Christian Fuchs; Routledge, 2014). Daniel completed a PhD in Sociology at Queen's University in Kingston, Canada.

QIAN HuANG is a Ph.D. Candidate at the Department of Media and Communication of Erasmus University Rotterdam The Netherlands. Her current research considers digital vigilantism on the Chinese Internet. Qian completed her master's study at the Chinese University of Hong Kong.

Rashid Gabdulhakov is a Ph.D. Candidate at the Department of Media and Communication, at Erasmus University Rotterdam, the Netherlands. As a member of an international team of scholars, he is researching the phenomenon of digital vigilantism and its manifestation in Russia and other former Soviet republics. Rashid has authored several articles in peerreviewed journals on this topic. 